\title{
Literatos, política e atuação profissional em Teresina no início do século $X X$
}

\author{
Writers, politics and professional activity in Teresina at the beginning of the 20th \\ century
}

\section{Teresinha Queiroz}

Doutora em História

Professora do Programa de Pós-Graduação em História da Universidade Federal do Piauí teresinhaqueiroz@bol.com.br

Ronyere Ferreira

Mestre em História pela Universidade Federal do Piauí rony-001@hotmail.com

Resumo: O presente artigo analisa as relações mantidas por um grupo de literatos, atuantes em Teresina, com a política nas primeiras décadas do século XX, escritores que se autodenominavam indiferentes e alheios às amarras partidárias. Por meio de fontes hemerográficas, sobretudo crônicas e notícias oficiais e biográficas destaca-se que os literatos, embora se declarando avessos às práticas e partidos políticos que regiam as esferas de poder, elaboravam pensamentos complexos, com críticas, propostas e projetos ao regime republicano, assim como flertavam constantemente com os detentores de poder, com o fito de desfrutarem as suas benesses e garantirem posições na burocracia estadual.
Palavras-chave: Literatos, política, Teresina Abstract: The present article analyzes the relations maintained by a group of writers, active in Teresina, with politics in the first decades of the 20th century, writers who called themselves indifferent and unrelated to party ties. By means of hemerographic sources, mainly chronic and official and biographical news, it is worth noting that the writers, although declaring themselves to be averse to the practices and political parties that governed the spheres of power, elaborated complex thoughts with criticisms, proposals and projects to the republican regime, just as they constantly flirted with the holders of power, in 
order to enjoy their blessings and secure Key-words: Writers., politics, Teresina. positions in the state bureaucracy.

O presente artigo analisa as relações mantidas por um grupo de literatos, atuantes em Teresina (PI), com os líderes e partidos políticos locais, durante as primeiras décadas do século XX, escritores que se consideravam avessos às amarras partidárias. Por meio de crônicas, escritos memorialísticos e notícias de jornais visa-se delinear seus posicionamentos em frente às práticas, partidos e sujeitos que regiam as esferas de poder, posturas por vezes críticas, com propostas e projetos ao regime republicano, contendo igualmente aproximações e flertes momentâneos.

Nesse período, Teresina ainda era uma cidade pequena, com diversas limitações estruturais, entretanto, possuía uma intensa produção intelectual, divulgada especialmente por meio dos vários periódicos que surgiam, geralmente de existência efêmera e empreendidos tanto por homens consagrados nas hostes letradas locais, como por jovens aspirantes ao mundo das letras, com anseios de realização literária e social.

Essa juventude, apressada por fazer acontecer, por se posicionar em postos de prestígio e por inscrever seu nome na literatura piauiense, era formada, geralmente, por egressos do curso secundário, acadêmicos e recém-formados, que se dispersavam em seus círculos de amizade, a dinamizar a imprensa e a cultura local.

Um desses grupos e que se configura como objeto dessa pesquisa, era formado por Jônatas Batista, ${ }^{1}$ Edison Cunha, ${ }^{2}$ Antônio Chaves, ${ }^{3}$ Celso Pinheiro ${ }^{4}$ e Zito Batista ${ }^{5}$, jovens literatos que desde os primeiros anos do século XX ensaiavam ousadias intelectuais, tornando-se responsáveis por uma intensa produção literária, em verso e prosa. Formaram

\footnotetext{
1 Jônatas Batista nasceu em 1885 no povoado Natal, falecendo em 1935, em São Paulo. Ainda criança, mudou-se a Teresina, onde estudou até o secundário, foi escrivão da antiga Mesa de Rendas, subdelegado de polícia, jornalista, dramaturgo, cronista e poeta. Foi um dos fundadores da Academia Piauiense de Letras e destacou-se por sua militância cultural. Publicou dois livros de poemas, Sincelos (1906) e Alma sem rumo (1934). Redigiu e colaborou com muitos jornais no Piauí e em outros estados. Cf: FERREIRA, 2015: 143151.

${ }^{2}$ Edison da Paz Cunha nasceu em 1891, falecendo em 1973. Formado pela Faculdade de Direito do Recife, atuou como poeta, jornalista, professor, advogado e promotor, além de ter ocupado diversos cargos administrativos no Piauí. Foi um dos fundadores da Academia Piauiense de Letras. Entre suas obras estão: Razões finais, em coautoria (1941), Correspondência para você (1943) e Vozes imortais (1945). Redigiu e colaborou com muitos jornais em Teresina. Cf.: ADRIÃO NETO, 1995: 97; MOURA, 2014: 23.

3 Antônio Chaves nasceu em 1882, falecendo em 1938. Foi poeta, jornalista, conferencista e um dos fundadores da Academia Piauiense de Letras. Entre suas obras estão: Almas Irmãs (1907), em parceira com Celso Pinheiro e Zito Batista; Nebulosas (1916); e Poema da mágoa (1919). Foi redator e colaborador de vários jornais em Teresina. Cf.: GONÇALVES, 2000: 59-62; MOURA, 2014: 19.

${ }^{4}$ Celso Pinheiro nasceu em 1887, falecendo em 1950. Foi poeta, jornalista e cronista, com sua obra marcada pelo pessimismo. Ocupou a cadeira de número 10 da Academia Piauiense de Letras. Entre suas obras estão: Almas irmãs (1907), em parceria com Antônio Chaves e Zito Batista; Flor incógnita (1912); e Poesias (1939). Cf.: GONÇALVES, 2000: 121-123; MOURA, 2014: 10-12.

${ }^{5}$ Raimundo Zito Batista nasceu em 1887, falecendo em 1926. Foi poeta, professor e jornalista, redigiu e colaborou em diversos jornais no Piauí e outros estados. Entre suas obras estão: Almas Irmãs (1907), em parceria com Antônio Chaves e Celso Pinheiro; Chama Extinta (1918); Harmonia dolorosa (1924); e Poesias reunidas (1924). Cf.: GONÇALVES, 2000: 423-426; PINHEIRO, 2014: 184-185.
} 
um grupo fecundo, de intensas e variadas iniciativas intelectuais, comungando o desejo de consolidarem-se social e economicamente.

Alguns desses literatos buscavam esquivar-se das contendas políticas, que se exaltavam por meio da imprensa, nutrindo em meio ao grupo a crença de que o melhor posicionamento em frente à política local seria o distanciamento, até mesmo a indiferença, o alheamento.

$\mathrm{O}$ presente artigo analisa as relações desse grupo de literatos com a política piauiense das primeiras décadas do século XX, buscando identificar nuances e fissuras em seus discursos e trajetórias sociais, com o intuito de decodificar e confirmar ou contrariar as relações que mantinham e afirmavam manter com a política e seus sujeitos. Esses escritores são compreendidos como representativos dos caminhos possíveis de atuação em meio a uma sociedade marcada pelas polarizações partidárias, que influenciavam fortemente a vida social da cidade, entre eles a atuação prática dos homens letrados, que geralmente eram empregados nas repartições públicas.

Essas relações ganham relevo, sobretudo, por meio dos periódicos que circulavam na cidade e de relatos memorialísticos dos sujeitos que viveram no período, fontes que não são compreendidas como a reprodução objetiva da realidade, mas como resquícios humanos que devem ser indagados e interpretados.

Embora representativos e integrantes de um círculo de amizade, esses literatos não são entendidos como membros de um grupo coeso em ideias ou atitudes. É importante ressaltar que os relacionamentos com os partidos políticos variavam significativamente entre os grupos sociais, assim como entre os subgrupos, isso ocorria devido à heterogeneidade cultural de seus integrantes, detentores, muitas vezes, de tradições culturais diferentes, abertos a mudanças de interesses ou valores, que se desenvolviam por meio de processos de diferenciação ou rupturas internas (Cf.: WILLIAMS, 1992).

Os literatos desse grupo buscavam diferenciar-se daqueles inseridos em militâncias políticas, ostentando com satisfação a suposta indiferença. Jônatas Batista, em crônica de 15 de julho de 1909, publicada no primeiro número da revista Alvorada, ${ }^{6}$ ao discorrer sobre os debates envolvendo as eleições presidenciais, desculpou-se por adentrar em um assunto que, notoriamente, não fazia parte de sua preferência, já que optava por temas menos apaixonantes:

\footnotetext{
${ }^{6}$ Periódico quinzenal e de tamanho variado, era fruto do consórcio entre os literatos Jônatas Batista, Antônio Chaves, Pedro Borges, Celso Pinheiro e Zito Batista. Seu conteúdo era composto de crônicas sociais, críticas literárias, poemas e artigos sobre sociabilidades e moda. Entre seus colaboradores estavam intelectuais renomados no Piauí, entre eles Higino Cunha, Clodoaldo Freitas, João Pinheiro e Simplício Mendes.
} 
O leitor, se não é muito inclinado às discussões políticas, como acontece com o escrevinhador destas linhas, desculpar-me-á, por certo, se me deixei levar por esse caminho, onde se debatem constantemente milhares de opiniões diversas (BATISTA, 1909: 3).

A crônica voltava-se, preocupadamente, à candidatura do militar Hermes da Fonseca à presidência do Brasil, um homem considerado impopular, sem confiabilidade para assumir o cargo máximo da nação. O militar já teria, segundo o literato, angariado hostilidades de políticos residentes em diferentes estados, entre eles São Paulo, Rio de Janeiro, Minas Gerais e Bahia. Jônatas Batista, embora opondo-se à candidatura de Hermes da Fonseca, mostrava-se receoso, mas não propôs uma alternativa ao impasse e desviou-se por meio da suposta indiferença que nutria pelo assunto.

Outro relato dessa impassibilidade encontra-se em recordação de Edison Cunha, publicada em 1943, pela Revista da Academia Piauiense de Letras, ${ }^{7}$ onde igualmente se destacou essa suposta insensibilidade com as questões políticas, descaso que se constituía, segundo informa, uma das características de seu círculo de amizade, o que proporcionou aos jovens literatos a denominação pejorativa de "os poetas":

Mas, voltando ao passado, formávamos um grupo tido como indisciplinado, por que não nos acomodávamos às normas e exigências dos partidos políticos, em torno dos quais gravitava a vida social teresinense. Vivíamos à [sic] eles indiferentes, ciosos de nossa liberdade de pensamento, do direito de dizer, escrever e gritar o que nos viesse à telha. Embora não vissem com bons olhos essa rebeldia, os dirigentes das agremiações partidárias não lhe opunham obstáculos e limitavam-se a chamar-nos, pejorativamente, os poetas. Éramos para eles os poetas, como tal, sem responsabilidade nos conceitos de sonhadores (CUNHA, 1943: 39, grifo do autor).

O grupo ao qual se refere Edison Cunha era formado sobretudo por ele, Jônatas Batista, Antônio Chaves, Celso Pinheiro e Zito Batista, que se distanciavam das trajetórias políticas de renomados literatos piauienses - entre eles Higino Cunha e Clodoaldo Freitas, para citar aclamados pelos próprios - que, com frequência estavam

\footnotetext{
${ }^{7}$ Revista da Academia Piauiense de Letras, instituição fundada em dezembro de 1917. Essa publicação iniciou-se em 1918, redigida por intelectuais que ocupavam cadeiras na instituição e veiculava artigos sobre história, geografia, literatura, além de poesias, contos e textos dramatúrgicos. Entre seus colaboradores encontram-se seus integrantes, piauienses residentes em outros estados e escritores de reconhecimento nacional.
} 
envolvidos em contendas partidárias, angariando para si, por vezes, hostilidades, ostracismo e momentos de dificuldades financeiras.

Clodoaldo Freitas, ${ }^{8}$ formado pela Faculdade de Direito de Recife, era vinculado na década final do Império ao Partido Liberal, o que proporcionou um início de carreira confortável, pois o partido encontrava-se na situação. Isso possibilitou que ocupasse, assim que voltou ao Piauí, cargos relevantes na burocracia provincial em Teresina e em outras cidades do interior. Entretanto, a prosperidade dos primeiros anos na magistratura foi interrompida pela assunção ao poder do Partido Conservador em 1885, proporcionando-lhe um afastamento dos cargos públicos, destinando-se à imprensa e à advocacia.

A vida do intelectual foi marcada pela peregrinação espacial, residindo em alguns estados, entre eles Maranhão e Pará, andanças motivadas, sobretudo, por perseguições políticas e poucas possibilidades de atuação enquanto se encontrava na oposição. Segundo Teresinha Queiroz, a vida profissional de Clodoaldo Freitas foi marcada "pela instabilidade e pela insegurança", sendo explicável à luz de "sua acidentada participação política desde o Império.” (QUEIROZ, 2011: 129)

Embora menos conturbada, a vida de Higino Cunha ${ }^{9}$ também foi marcada pela militância política, por seus bônus e ônus. Igualmente ligado ao Partido Liberal e formado pela Faculdade de Direito de Recife, quando chegou a Teresina em 1885 atuou como redator de periódicos liberais, e até 1900 ocupou diversos cargos, em anos de instabilidade financeira e de frequente deslocamento espacial. Segundo Teresinha Queiroz: “

[...] A partir de 1900, quando suas ocupações principais se definem, só terá um episódio de acintosa perseguição política - a demissão em 1915, por Miguel Rosa, dos cargos vitalícios tanto de Procurador dos Feitos da Fazenda, como de professor do Liceu Piauiense (2011: 128).

Mostra-se interessante o contraste da disposição política dos "poetas" e os dois exemplos citados. Embora nutrissem profunda admiração por Clodoaldo Freitas e Higino Cunha, o segundo aclamado Mestre pelo grupo, suas trajetórias tortuosas divulgavam os

\footnotetext{
${ }^{8}$ Clodoaldo Severo Conrado de Freitas nasceu em Oeiras em 1855 e faleceu em Teresina em 1924. Foi magistrado, jornalista, político, poeta, historiador, romancista e cronista. Foi um dos fundadores da Academia Piauiense de Letras e entre suas obras encontram-se: Vultos piauienses (1903); Em roda dos fatos (1911); Os burgos (1912); e História de Teresina. Cf.: QUEIROZ, 1996: 5-18.

${ }_{9}^{9}$ Higino Cícero da Cunha nasceu em 1858 e faleceu em 1943. Foi magistrado, professor, historiador, jornalista, poeta e um dos fundadores da Academia Piauiense de Letras, entre suas obras encontram-se: $O$ teatro em Teresina; $O$ idealismo filosófico e o ideal artístico; e História das religiões no Piauí. Ver: ADRIÂO NETO, 1995, p. 97.
} 
perigos proporcionados pela militância política, caminhos instáveis, cada dia menos atraentes para uma elite letrada, desejosa de estabilidade e aspirante a colocações na burocracia republicana.

Segundo o relato de Edison Cunha, seu grupo nutria orgulhosamente a suposta indisciplina, ostentando por meio dos periódicos um livre pensamento, sem amarras partidárias. Esse comportamento beneficiava-lhes com amplo acesso nas redações dos jornais da cidade, situacionistas, oposicionistas ou supostamente independentes, entretanto, uma análise mais detida das trajetórias desses escritores revela fraturas significativas nas representações que intentavam construir para si.

Em olhar panorâmico, a política não se apresentava como uma temática recorrente na escrita desses literatos, ainda assim, pode-se identificar a elaboração de análises sistemáticas sobre o regime político que vivenciavam, com críticas, propostas e coligações com os políticos que detinham o poder. Na documentação coligida, sobressai ainda a forte oposição entre os regimes republicano e monarquista, embora o último tivesse se extinguido desde 1889. Essa ênfase deve-se em grande medida à necessidade de denunciar os rumos que os governos republicanos estavam tomando, frequentemente associados aos caminhos de exclusão percorridos durante o Império.

Os escritos de Jônatas Batista são exemplares nesse sentido, tornando-o representativo da metodologia de atuação dos integrantes desse grupo por meio da escrita, onde a política aparece tangencialmente, ocupando as margens das narrativas, ainda assim de maneira consciente e com propósitos implícitos capazes de ser interpretados.

Ativo na imprensa e publicando em diversos gêneros literários, Jônatas Batista evidenciou por meio de crônicas os problemas vivenciados nos bairros pobres de Teresina, criticando os governantes pelo abandono do povo e pelo descaso com as regiões periféricas da cidade, responsável pelo gritante contraste com as regiões centrais, que já passavam por um processo de modernização urbana (BATISTA, 2015: 219; 222; 223). Esses escritos sobre os excluídos constituíam-se nos alicerces que sustentavam a apresentação do que considerava um tipo ideal de político, que deveria ser envolto no patriotismo e na elevação intelectual.

Para o literato, os líderes políticos deveriam ter características que os qualificasse para o exercício do poder, um governante devia ter trajetória capaz de angariar, por conta própria, respeito, dignidade e confiança, sem a necessidade dos apadrinhamentos característicos da Primeira República. Qualidades consideradas imprescindíveis a um candidato que deveria igualmente ter boas ações, uma "[...] inteligência superior e um patriotismo a toda prova" (BATISTA, 1909: 4). 
Os governantes ideais, segundo acentuava, deveriam estar a serviço da população, especialmente dos mais pobres, os que assim procedessem seriam merecedores de aplausos e elogios de todo e qualquer cronista. Em publicação de 30 de novembro de 1909, louvou a atitude do então presidente Nilo Peçanha, que naquele ano, durante as comemorações do vigésimo aniversário da proclamação da República, patrocinou com vinte contos de réis as funções de teatros e cinematógrafos do Rio de Janeiro aos operários e suas famílias (BATISTA, 2015: 141). Esse gesto seria um verdadeiro ato de democracia, pois considerava que, em geral, o alcance do posto mais alto do país, coincidia com o esquecimento dos pobres, que eram afastados dos momentos importantes da nação:

E esses elogios, esses aplausos sobem de ponto ao lembrarmo-nos de que os vinte contos de réis despendidos, com o fim de que os obscuros brasileiros também pudessem bendizer, naquele dia, a grande data que festejava, foram retirados de sua bolsa, num impulso raro, de muito patriotismo, num exemplo edificante da mais perfeita democracia. Da mais perfeita democracia, sim; porque, em geral, os que chegam a certa altura, a certas posições políticas ou sociais, esquecem sempre os pequenos, os medíocres, tratando mesmo de afastá-los do grande concerto da civilização, no mais exagerado requinte de egoísmo e... imbecilidade (BATISTA, 2015: 141).

Por meio de sua crítica aos líderes republicanos, o literato propunha, de certa forma, que o regime fosse reformado, pois estaria ainda com aspectos característicos de uma monarquia, caracterizada por ele como egoísta, individualista e excludente, mantenedora das bases da escravidão. Esses posicionamentos, longe de ser exclusividade de Jonatas Batista, são recorrentes na produção de diversos escritores do período em diversas regiões do Brasil, que criticava o regime republicano consolidado no início do século XX e visava à retomada dos princípios pregados, que nortearam a propaganda do regime nas décadas finais da monarquia. Segundo Teresinha Queiroz:

[...] surge na imprensa brasileira um viés de crítica feita especialmente pelos republicanos históricos alijados dos quadros de mando político, como um dos grupos expurgados visando à consolidação e homogeneidade da proposta de república vitoriosa. Esses críticos, abrigados por vezes nos quadros das oposições oligárquicas locais, usam o espaço da imprensa para a veiculação das propostas políticas a que nos referimos como de republicanização da República (2015: 23). 
As críticas de Jônatas Batista ao regime político que vigorava possuíam essência e insatisfação semelhante à de republicanos históricos que militavam na imprensa. Clodoaldo Freitas, intelectual ao qual Jônatas Batista esteve próximo, destacava em seus escritos que os governos estabelecidos constantemente negavam a essência do regime.

Para Teresinha Queiroz, a crítica de Clodoaldo Freitas centrava-se na negação da cidadania, que ocorria por meio da exclusão de mulheres e analfabetos do processo eleitoral, além da impossibilidade de livre escolha dos representantes políticos, pois imperavam as fraudes eleitorais e os diversos estratagemas para amedrontar eleitores da oposição (QUEIROZ, 2015: 25-26).

Para Jônatas Batista, uma republicanização da República dar-se-ia por reformadores que resgatariam a essência do regime, eles que deveriam ser guiados pela sabedoria e governarem para o povo. A oposição à candidatura do militar Hermes da Fonseca, segundo pontuamos anteriormente, é representativo das preferências políticas do literato, que visavam romper com os vícios instaurados e construir novos rumos ao regime republicano, esperanças depositadas na candidatura do baiano Rui Barbosa à presidência, considerado um exemplo, pelo amor à pátria e às letras.

Em meio à caótica consolidação das instituições republicanas, os maculados princípios do regime, as fortes críticas que se faziam aos políticos e aos partidos corruptos, desprovidos de ideologias e capacidade técnica, o apoio à candidatura de Rui Barbosa deu-se por diversos grupos de intelectuais, significando uma alternativa viável em frente à possibilidade de novamente um militar assumir a presidência (SEVCENKO, 2003: 107-110).

Rui Barbosa localizava-se, embora fosse candidato das oligarquias paulistas, em um perímetro de idealização de Jônatas Batista e muitos outros letrados do período, assim como outros políticos sensíveis às letras, entre eles Abdias Neves, Coelho Neto e Félix Pacheco. Os líderes políticos indiferentes ao povo e às letras, para Jônatas Batista, encontravam-se na "classe de homens vulgares, dos homens que se não preocupam com os problemas máximos e superiores da existência, vivendo vida subalterna, vivendo fora das letras, das artes e da ciência" (BATISTA, 2015: 167). Propunha-se uma república gerenciada por homens cultos e com ampla participação popular em seus momentos.

Ao passo que criticava o regime republicano, avigorava a oposição ao modelo monárquico, que para ele seria o exemplo máximo de repúdio à população, de egoísmo e de exploração, mantenedora do regime escravista e de todos os seus horrores (Cf.: BATISTA, 1920: 3), um regime que buscava somente saciar desejos pessoais, provocando sofrimento e desamparo ao povo. Não por coincidência, em 1909 o literato criticava aspectos semelhantes no regime republicano, destacando-o como monárquico, 
egoísta (Cf.: BATISTA, 2015: 141), imerso em decepções causadas "pelos interesses pessoais, pelas camaradagens compadrescas [...] vagando sem rumo, no revolto oceano do egoísmo e dos interesses pessoais" (BATISTA, 1909: 3).

A ênfase da crítica aos governos republicanos centrava-se na equiparação ao regime monárquico, pois o literato constatava a continuidade de características, como o abandono do povo e a inacessibilidade das esferas de poder por ampla parte dos intelectuais.

A escrita de Jônatas Batista e a forma como abordava temáticas políticas são concernentes a uma nova concepção de atuação política, que crescia em meio aos integrantes de uma elite letrada e aspirante à burocrática estadual, consistindo, sobretudo, em uma postura supostamente neutra e indiferente, esquivando-se das polêmicas ruidosas e traumáticas protagonizadas pelas facções políticas das primeiras décadas do século XX.

Outro caminho que possibilita flagrarmos os relacionamentos que esse grupo de literatos mantinha com a política, passa pelo rastreamento de suas vidas práticas, em outros termos, pelo mapeamento de suas atitudes que visavam garantir a sobrevivência material individual e familiar, visto que os empregos públicos constituíam-se em colocações almejadas por eles e dependiam, em dimensão significativa, da fluência de seus relacionamentos com os grupos políticos.

Entre os literatos atuantes em Teresina, sobretudo na primeira década do século $\mathrm{XX}$, que buscavam reconhecimento social como homens de letras, poucos possuíam condições financeiras tranquilas, ocasionando que muitos não tivessem acesso às faculdades superiores.

Jônatas Batista desde cedo voltou-se ao trabalho para garantir o sustento familiar, não concretizando os planos de ingressar em uma faculdade e levando-o a exercer diversos cargos de pouca relevância na burocracia estadual. Zito Batista, igualmente colocou-se desde jovem no mundo do trabalho, ocupando cargos públicos secundários e convivendo com frequentes atribulações financeiras, o que certamente contribuiu para sua migração para o Rio de Janeiro, onde atuou como escrivão e impôs-se na imprensa periódica. Aliás, entre as últimas décadas do século XIX e as primeiras do século XX, não foram poucos os literatos que, motivados por questões financeiras, destinaram-se a outros centros urbanos do país.

As dificuldades financeiras não eram privilégio de uma minoria, afligiam quantidade significativa daqueles que possuíam propensão ao mundo das letras, e eram inúmeros os exemplos de privações econômicas em suas biografias, alguns deles ao financiarem núpcias: Higino Cunha, em suas memórias, publicadas originalmente em 1939, narra as dificuldades para conseguir arcar com os dois contos de réis referentes às despesas do casamento de sua primogênita, Durcila, com o então jovem literato Jônatas 
Batista, o que somente foi possível com a ajuda de discípulos e amigos (CUNHA, 2011: 80-81); Lucídio Freitas, filho de Clodoaldo Freitas, formado em Direito por uma faculdade do Rio de Janeiro, ao contratar casamento com uma moça de Belém, onde residia, "se desesperava em busca de dois contos de réis para financiar as despesas nupciais" (QUEIROZ, 2015b: 188).

Em escala local, essa limitação econômica justifica-se em parte pelo reduzido mercado de trabalho em Teresina, onde a sobrevivência material era um desafio diário para a maioria da população. Os detentores de formação superior possuíam maiores possibilidades de ocupação no aparelho burocrático estadual e federal, ou por meio de prestações de serviços ao estado, aulas particulares ou por atuação em suas áreas de formação. Dentistas, farmacêuticos, médicos e advogados ofereciam seus serviços em anúncios nos periódicos.

Os jovens que conseguiam cursar o ensino secundário, em comparação à massa de analfabetos ou detentores de primeiras letras, vislumbravam condições de emprego intermediárias. Entretanto, formavam no decorrer das primeiras décadas do século XX um grupo numeroso, cuja absorção era difícil por meio do funcionalismo público, casas comerciais ou outras atividades que exigissem conhecimentos escolares mais elementares, entre elas o magistério, atividade exercida por muitos, como Higino Cunha, Zito Batista, Celso Pinheiro e Edison Cunha.

Outra área de atuação profissional possível aos literatos, com ou sem formação superior, era a imprensa, no entanto, os periódicos circulantes em Teresina forneciam escassos postos de trabalho, geralmente para chefe de redação, revisores e tipógrafos. Poucos eram os periódicos teresinenses que pagavam pelas produções escritas de seus colaboradores e, quando existentes, eram remunerações pequenas. As relações entre as redações e os colaboradores pautavam-se na maioria das vezes em permutas, em troca de suas produções, os literatos recebiam as assinaturas das folhas.

Tornar-se dono de um periódico não era uma alternativa economicamente viável, embora fosse empreendida por vários jovens literatos. O elevado preço do papel e suas diversas crises, a pouca proporcionalidade de leitores na cidade e a inviabilidade de manutenção por meio de anúncios e assinaturas eram as principais limitações à redação de periódicos, comumente redigidos por um grupo de amigos, que na maioria das vezes arcavam parcialmente com os custos das impressões, com recursos oriundos das outras atividades que desempenhavam.

As pretensões de muitos literatos era uma aprovação em concurso público, capaz de proporcionar estabilidade social e maior conforto familiar, tirando-os da mira das suscetibilidades partidárias, que proporcionavam renovações agudas nas repartições 
públicas, assim que havia alternância de poder entre os grupos políticos. Os concursos eram, geralmente, vitalícios e realizados por homens de diferentes classes sociais, com exigência de idade entre 18 e 40 anos. Eram rígidos crivos entre os letrados para inserção na burocracia, pois estabeleciam a obrigação de conhecimentos variados. Um praticante de telegrafia, por exemplo, devia apresentar atestados de capacidade intelectual e submeter-se a exames de aritmética e diferentes línguas - português, alemão, francês, inglês, etc.

Uma aprovação nesses certames mostrava-se determinante para projetos de efetivação social, segundo se verifica no testemunho Zut, em crônica de fevereiro de 1912:

Que diabo! Onde estavam o nosso talento e a nossa capacidade de estudo! Pois devíamos fugir do concurso, nós que já havíamos feito, regularmente, o exame de iguais matérias, no Liceu?

E não era somente isso que nos enchia de coragem. Atrás do concurso, depois de um ano, ou dois, estaríamos no exercício de um cargo federal, vitalício, fartamente remunerado.

Caminhávamos, assim, para um bom casamento, uma casinha alegre, mobiliada, clara, uma mulher bonita, um casal de filhos...

Era o Ideal... Era a Felicidade, tudo isso com letras maiúsculas, tudo coisa verdadeira, real, fora de dúvida (ZUT, 1912: 3).

A crônica de Zut, pseudônimo criado por Zito Batista, informa sobre concurso prestado por ele e Celso Pinheiro para ocupação de cargos na repartição dos telégrafos, que ocorria em fevereiro de 1911 (ESTÃO..., 1911: 1; TERMINOU..., 1911: 1). As expectativas de estabilidade por meio de um cargo vitalício expostas pelo cronista podem ser ampliadas ao grupo do qual fazia parte, visto ter sido o caminho percorrido por alguns deles, assim como à juventude letrada da cidade, o que se nota por meio da listagem dos concorrentes, com sujeitos pertencentes tanto a famílias tradicionais como às em ascensão.

O objetivo central da crônica de Zut era homenagear o Diário do Piauí ${ }^{10}$ em seu primeiro aniversário, isso por meio do testemunho sobre o cotidiano na redação durante os primeiros meses de sua circulação. Segundo Zut informa-nos, seu ingresso e o de Celso

\footnotetext{
${ }^{10}$ O Diário do Piauí era o jornal oficial do estado, circulou em Teresina de 1911 a 1914. Seu redator chefe era Simplício Mendes. Além do expediente oficial e dos atos do poder executivo, publicava poesias, crônicas e folhetins. Contava com a colaboração de diversos literatos piauienses, entre eles Clodoaldo Freitas, Higino Cunha, Lucídio Freitas, Jônatas Batista, Antônio Chaves, Zito Batista e Abdias Neves.
} 
Pinheiro como revisores na redação do jornal ocorreu a convite de Simplício Mendes, ${ }^{11}$ então diretor da Imprensa Oficial, isso em meio a atribulada preparação para as etapas finais do concurso dos telégrafos. Essa informação permite-nos flagrar uma das maneiras mais comuns de inserção no aparelho público, mecanismo plenamente legítimo no período.

Colocações como essas, que exigiam habilidade de escrita e leitura eram comuns aos integrantes desse grupo de literatos, geralmente de ordenado pequeno, que garantia o sustento pessoal e muitas vezes familiar. Tais empregos eram conquistados por diferentes maneiras: reconhecimento intelectual pelos pares, recompensa ou apoio político, relações de amizade ou parentesco.

Sobre a necessidade de amizades que viabilizassem o ingresso na burocracia oficial é exemplar a nomeação de Zito Batista ao cargo de praticante dos telégrafos de Teresina, conseguida por meio de interferência de Raimundo Artur de Vasconcelos no Rio de Janeiro, segundo informe exultante de telegrama em 6 de julho de 1912 (O NOSSO..., 1912: 2), cargo assumido em meados de agosto do mesmo ano (COMUNICA-NOS..., 1912: 1).

Ainda que não seja possível confirmar a forma de ingresso de Zito na função, se por meio do concurso prestado em fevereiro de 1911 ou por nomeação direta, evidenciase a intercessão realizada por Raimundo Artur de Vasconcelos na capital federal, desvelando novamente a importância de influências para a concretização do acesso à burocracia republicana, visto que aprovações em concursos poderiam gerar anos de espera pela nomeação.

Embora trabalhando como praticante de telegrafia, Zito Batista atuava ainda como revisor no Diário do Piauí, função que exercia desde fevereiro de 1911, quando iniciou sua circulação, e redator da revista Cidade Verde. ${ }^{12} \mathrm{O}$ exercício simultâneo de diversas atividades era uma característica marcante da atuação profissional desses jovens literatos. Jônatas Batista, embora tenha sido escrivão da antiga Mesa de Rendas entre 1905 e 1920, atuou nesse intervalo como redator em diversos jornais, produtor cultural, subdelegado de polícia e advogado rábula.

\footnotetext{
${ }^{11}$ Simplício de Sousa Mendes nasceu em 1882 e faleceu em 1971. Formado pela Faculdade de Direito de Recife, foi juiz, desembargador, deputado estadual, diretor da Imprensa Oficial, chefe de polícia, fundador e professor da Faculdade de Direito do Piauí. Integrou a Academia Piauiense de Letras, redigiu e colaborou com diversos periódicos do Piauí. Entre suas obras estão: O ideal cristão (1926), Propriedade Territorial do Piauí (1928) e O homem, a sociedade, o Direito (1934). Cf.: CUNHA, 2014: 74-77; MOURA, 2014: 30-31.

${ }^{12}$ Revista literária quinzenal, publicada pelo Clube dos Simples e redigida por Zito Batista. Promovia concursos variados. Entre seus colaboradores encontrava-se Celso Pinheiro, Jônatas Batista, Simplício Mendes, Clodoaldo Freitas, Antônio Chaves, Higino Cunha e Abdias Neves.
} 
O Diário do Piauí iniciou sua circulação em 1911, quando o Piauí era governado por Antonino Freire, ${ }^{13}$ e teve papel fundamental para que o Partido Republicano Conservador elegesse o então diretor da instrução pública, Miguel Rosa, ${ }^{14}$ ao governo em 1911. Os governos de Antonino Freire e, pelo menos os dois primeiros anos da administração de Miguel Rosa, ficaram marcados por significativo apoio dos intelectuais e oposição ferrenha de militantes católicos, que os combatiam por serem declaradamente maçons. Essa conjuntura é fundamental para a compreensão das relações que os literatos estabeleciam com a política partidária, pois foram momentos de frequente inserção deles no serviço burocrático, ocupando diversos cargos do primeiro e do segundo escalão.

Um mapeamento detalhado das atividades profissionais desempenhadas por esses literatos, durante o período que residiram em Teresina, poderia informar e dar indicativos sobre as relações que mantinham com as facções partidárias em diferentes mandatos. Para o presente artigo, fazemos uso dessa metodologia para acompanhá-los durante os governos de Antonino Freire e Miguel Rosa, devido à vasta existência de fontes e por indicar uma tênue e velada atuação política, decodificando a regência das relações de cordialidade e apreço que envolviam suas relações com os líderes políticos da situação.

Em 13 de setembro de 1911, o Diário do Piauí, ao divulgar o seu nome, parabenizava Zito Batista por sua efetivação como escriturário da Imprensa Oficial (POR..., 1911: 1), cargo que já exercia desde o início do jornal, onde o literato ocuparia interinamente a direção em dezembro de 1912, durante o período em que o então diretor, Simplício Mendes, encontrava-se enfermo (O EXMํ.., 1912: 2). Em 14 de setembro de 1911 divulgava-se a nomeação de Edison Cunha para o cargo de segundo escriturário, e no mês seguinte para chefe da segunda seção de escriturários da Secretaria de Governo, cargo que já ocupava interinamente e que permaneceu mesmo durante longas viagens ao Recife, onde cursava Direito (Cf.: FORAM..., 1911: 1; O EXM..., 1911: 1; TROUXENOS..., 1911: 1).

Após formar-se, em abril de 1913, Edison Cunha logo foi nomeado promotor adjunto da Comarca de Teresina, cargo ocupado simultaneamente com a chefia da segunda seção de escriturários da fazenda e com a advocacia, que exercia ao lado do pai,

\footnotetext{
${ }^{13}$ Antonino Freire nasceu em 1878 e faleceu em 1934. Engenheiro civil pela Escola Politécnica do Rio de Janeiro, atuou como político, jornalista, diretor de obras públicas e governador (1910-1912). Foi um dos fundadores do Instituto Histórico e Geográfico do Piauí, publicou Limites entre os estados do Piauí e do Maranhão (1907) e Limites do Piauí (1921), e colaborou em periódicos circulantes em Teresina. Cf. PINHEIRO, 2014, p. 167-169.

${ }^{14}$ Miguel de Paiva Rosa nasceu em 1876 e faleceu em 1929. Formado pela Faculdade de Direito de Recife, atuou como advogado, jornalista, político, professor, procurador da República e diretor da Instrução Pública e ocupou o cargo de Governador de 1912 a 1916. Em Teresina fundou e colaborou com diversos periódicos. Cf. PINHEIRO, 2014, p. 174.
} 
Higino Cunha. Até voltar formado do Recife, o literato desfrutou de pelo menos quatro licenças para tratamento de saúde, entre fevereiro de 1912 e maio de 1913, propiciando que, nesse ínterim, o literato estivesse mais de licença do que no exercício de suas funções. Embora fossem concedidas para tratamento de saúde, evidencia-se que Edison Cunha aproveitou para realizar viagens ao Recife, onde cursava Direito, o que insinua o uso desse procedimento para viabilizar o término de sua formação. ${ }^{15}$

Estratagema semelhante utilizou Zito Batista, que solicitou e teve atendido um pedido de três meses de licença para tratamento de saúde, em agosto de 1913, contudo, no mês seguinte noticiava-se sua viagem ao Rio de Janeiro. Em julho de 1914, consta a prorrogação por mais três meses de uma licença em vigor, igualmente para tratamento de saúde, sendo que Zito ainda se encontrava na capital federal, onde passou a residir definitivamente.

Outros foram os literatos que se beneficiaram durante o governo de Antonino Freire e os dois primeiros anos do mandato de Miguel Rosa, entre eles Celso Pinheiro e Antônio Chaves. O primeiro, conforme sublinhamos anteriormente, atuou como revisor do Diário do Piauí, e Antônio Chaves como segundo escriturário da Secretaria da Fazenda (POR ATO..., 1911: 1).

É importante ressaltar que as posições conquistadas por esses literatos na esfera governamental, durante os governos de Antonino Freire e Miguel Rosa, originam-se, em grande medida, da proximidade política que mantinham com os governadores, pois, embora buscassem manter uma postura de aparente neutralidade e independência, conservavam-se perto dos líderes situacionistas.

Por meio dos jornais é possível encontrá-los em diversos acontecimentos políticos envolvendo os líderes do Partido Republicano Conservador. Recepções após viagens, bailes, aniversários, convenções partidárias, constituíam-se momentos propícios a ver e ser vistos, a manifestar apreço e proximidade. Em outubro de 1911 grande festa recepcionou o então diretor da instrução pública, Miguel Rosa, com presença de diversas personalidades, entre eles Jônatas Batista, Antônio Chaves, Zito Batista e Celso Pinheiro (DR. MIGUEL..., 1911: 1), que se fizeram presentes também em baile realizado no palácio do governo, em honra do futuro governador (ESTEVE..., 1911: 1).

As festas e elogios em homenagem a Miguel Rosa, noticiadas fartamente por meio do Diário do Piauí, visavam consolidar seu nome como candidato a governador, o que se confirmou em 12 de outubro de 1911 na convenção do Partido Republicano Conservador,

\footnotetext{
${ }^{15}$ Sobre as licenças e as viagens de Edison Cunha à cidade de Recife, suas nomeações e licenças de saúde, Cf.: TROUXE-NOS..., 1911: 1; NOMEANDO. 1911: 2; PELO..., 1912: 1; DIA..., 1912: 2; AO SECRETÁRIO..., 1912: 2; DE VOLTA..., 1912: 1; NOMEADOS... 1912: 2; CONCEDENDO..., 1912: 2; CONCEDENDO..., 1913: 2.
} 
ocasião que contou com alguns oradores, entre eles "Celso Pinheiro, por delegação dos moços presentes", além do comparecimento de outros homens de letras, entre eles Edison Cunha, Antônio Chaves, Zito e Jônatas Batista (VÁRIAS..., 1911: 1).

O mapeamento desses acontecimentos e dos sujeitos que se faziam presentes são importantes para apreender a dimensão do movimento social ao redor dos governantes. Embora a presença desses literatos não signifique uma adesão ou militância ao Partido Republicano Conservador e seus líderes, evidencia o flerte que esses sujeitos mantinham constantemente com os políticos que se mantinham no poder, era a nutrição de relações de cordialidade, praticadas igualmente por outros grupos de letrados que, muitas vezes, competiam entre si.

Essas manifestações de apreço, embora pequenas e talvez até despercebidas, haja vista a grande quantidade de sujeitos que orbitavam ao redor dos líderes políticos, mostravam-se fundamentais na construção e manutenção de laços sociais, de estima e de solidariedade indispensáveis para a conquista ou manutenção de muitos empregos.

Tanto a produção escrita desses literatos quanto as trajetórias burocráticas que realizaram, convalidam questionamentos sobre a suposta indiferença política que ostentavam. Mais do que um testemunho sobre suas atuações, a identidade que buscavam construir tornou-se um mecanismo de isenção dos ônus políticos, pois, se a ausência de militância e adesão aos apaixonantes debates evitou premiações prestigiosas, igualmente evitaram eventuais ostracismos em consequência de possíveis derrotas eleitorais.

As mudanças verificáveis nas trajetórias desses literatos igualmente testemunham o caráter premeditado e estratégico da suposta indiferença que declaravam. Embora não se possa exigir e esperar coesão e trajetos lineares desses sujeitos históricos, certas mudanças, juntamente com outros indícios, informam sobre verdades que, na maturidade, podem ser enunciadas, embora não tenham sido durante períodos de consolidação social. Casos representativos são os de Edison Cunha e Jônatas Batista, que posteriormente abandonaram a rebeldia de outros tempos.

Edison Cunha, no livro Vozes imortais, publicado originalmente em 1945, ao descrever seu próprio perfil, já sublinhava ter praticado o “jornalista político”, com muita luta e pouca ascensão (CUNHA, 2014: 42). Jônatas Batista, após aprovações em concursos lhe terem levado a residir no Pará e depois em São Paulo, acabou por concorrer a uma vaga de deputado estadual em 1934, com candidatura avulsa e compondo a coligação dos independentes, ${ }^{16}$ angariando expressiva votação, cerca de 2.900 votos (QUADRO..., 1934: 2).

16 Sobre a candidatura de Jônatas a uma vaga de deputado em São Paulo, Cf.: BOLETIM..., 1934: 13; COLIGAÇÃO..., 1934: 26; COLIGAÇÃO..., 1934: 21. 
"Os poetas", literatos ditos indiferentes, comungaram com a desilusão dos rumos seguidos pelos governos republicanos, com a denúncia dos descasos com a população, entretanto, ao negarem suas preferências políticas em determinados contextos, buscavam defender-se das suscetibilidades partidárias e legitimarem-se como um círculo diferente e indiferente, não à política, mas às formas tradicionais de atuação dos literatos, pautadas em polêmicas políticas intermináveis e traumáticas, baseadas em manobras retóricas de descompostura moral e política dos adversários. Esses literatos, ainda jovens, propuseram uma nova forma de fazer política, pelas margens.

\section{Fontes}

AO SECRETÁRIO da fazenda [...]. Diário do Piauí. Teresina, ano 2, n. 54, 12 mar. 1912, p. 2.

BATISTA, Jônatas. Crônica. Alvorada, Teresina, ano 1, n. 1, 15 jul. 1909, p. 3. BATISTA, Jônatas. Crônica. Alvorada, Teresina, ano 1, n. 6, 30 set. 1909, p. 4.

BATISTA, Jônatas. Terra da luz. A Reforma, Vila Seabra (AC), ano 3, n. 84, 4 jan. 1920, p. 3.

BOLETIM Federal. Diário Oficial do Estado de São Paulo. São Paulo, ano 44, n. 223, 11 out. 1934, p. 13.

COMUNICA-NOS da estação [...]. Diário do Piauí. Teresina, ano 2, n. 174, 13 ago. $1912, p .1$.

CONCEDENDO ao chefe [...]. Diário do Piauí. Teresina, ano 3, n. 70, 27 mar. 1913, p. 2.

CONCEDENDO três meses [...]. Diário do Piauí. Teresina, ano 2, n. 278, 19 dez. 1912, p. 2.

CUNHA, Edison. Si rite recordor. Revista da Academia Piauiense de Letras, Teresina, ano 26, n. 20, dez. 1943.

DE VOLTA do Recife [...]. Diário do Piauí. Teresina, ano 2, n. 91, 3 maio 1912, p. 1.

DIA 11: ofício. Diário do Piauí. Teresina, ano 2, n. 37, 17 fev. 1912, p. 2.

DR. EDISON Cunha. Diário do Piauí, ano 3, n. 62, 15 mar. 1913, p. 1.

DR. EDISON Cunha. Diário do Piauí, ano 3, n. 92, 23 abr. 1913, p. 2.

DR. MIGUEL Rosa. Diário do Piauí. Teresina, ano 1, n. 156, 3 out. 1911, p. 1.

ESTÃo sendo procedidos [...]. Diário do Piauí. Teresina, ano 1, n. 1, 24 fev. 1911, p. 1.

ESTEVE delicioso o baile [...]. Diário do Piauí. Teresina, ano 1, n. 161, 12 out. 1911, p. 1 .

FORAM nomeados [...]. Diário do Piauí. Teresina, ano 1, n. 140, 14 set. 1911, p. 1.

LICENÇAS. Diário do Piauí. Teresina, ano 4, n. 158, 14 jul. 1914, p. 1.

NOMEADOS os médicos [...]. Diário do Piauí. Teresina, ano 2, n. 276, 17 dez. 1912, p. 2.

NOMEANDO o diretor interino [...]. Diário do Piauí. Teresina, ano 1, n. 166, 17 out. $1911, p .2$.

O EXM. SR. GOVERNADOR do estado [...]. Diário do Piauí. Teresina, ano 1, n. 162, 11 out. 1911, p. 1. 
O EXM‥ Sr. Dr. governador [...]. Diário do Piauí. Teresina, ano 2, n. 281, 22 dez. 1912, p. 2.

OFÍCIOS do governador. Diário do Piauí, ano 3, n. 139, 20 jun. 1913, p. 4.

OFÍCIOS. Diário do Piauí. Teresina, ano 3, n. 182, 13 ago. 1913, p. 1-2.

O NOSSO brilhante confrade [...]. Diário do Piauí. Teresina, ano 2, n. 142, 6 jul. 1912, p. 2.

PELO sr. dr. secretário de governo [...]. Diário do Piauí. Teresina, ano 2, n. 28, 6 fev. 1912, p. 1.

POR ato de ontem [...]. Diário do Piauí. Teresina, ano 1, n. 139, 13 set. 1911, p. 1.

POR ATO de ontem [...]. Diário do Piauí. Teresina, ano 1, n. 165, 15 out. 1911, p. 1.

QUADRO geral das apurações do pleito de 14 de outubro. Correio Paulistano. São Paulo, ano 81, n. 24.134, 25 out. 1934, p. 2.

TERMINOU, sábado passado [...]. Diário do Piauí. Teresina, ano 1, n. 3, 27 fev. 1911, p. 1.

TROUXE-NOS ontem [...]. Diário do Piauí. Teresina, ano 1, n. 166, 16 out. 1911, p. 1. VÁRIAS Notícias. Diário do Piauí. Teresina, ano 1, n. 164, 14 out. 1911, p. 1.

ZITO Batista. Diário do Piauí. Teresina, ano 3, n. 206, 12 set. 1913, p. 2.

ZUT. Nota ligeira. Diário do Piauí. Teresina, ano 2, n. 43, 24 fev. 1912, p. 3.

\section{Referências Bibliográficas}

ADRIÃO NETO (1995). Dicionário biográfico: escritores piauienses de todos os tempos. Teresina: Halley.

BATISTA, Jônatas (2015). Poesia e prosa. 2. ed. Teresina: Academia Piauiense de Letras.

COLIGAÇÃO dos independentes (1934). Diário Oficial do Estado de São Paulo. São Paulo, ano 44, n. 252, 18 nov, p. 26. . São Paulo, ano 44, n. 267, 7 dez, p. 21.

CUNHA, Edison (2014). Vozes imortais. 2. ed. Teresina: Academia Piauiense de Letras.

CUNHA, Higino (2011). Memórias: traços autobiográficos. 2. ed. Brasília; Teresina: Senado Federal; Academia Piauiense de Letras.

FERREIRA, Ronyere (2015). Jônatas Batista: 'a volubilidade e a inquietude'. Revista da Academia Piauiense de Letras. Teresina, ano 97, n. 72, 2015, p. 143-151.

GONÇALVES, Wilson Carvalho (2000). Antologia da Academia Piauiense de Letras. Teresina: [s. ed.], p. 59-62.

MOURA, Francisco Miguel de (2014). Posfácio a Literatura piauiense de João Pinheiro. Teresina: Academia Piauiense de Letras.

PINHEIRO, João (2014). Literatura piauiense: escorço histórico. 3. ed. Teresina: Academia Piauiense de Letras.

QUEIROZ, Teresinha (2014). Clodoaldo Freitas e a republicanização da República. In: História, literatura, sociabilidades. 2. ed. Teresina: EDUFPI/APL, p. . Homo sum (1996). In: FREITAS, Clodoaldo. Em roda dos fatos. 2. ed. Teresina: Fundação Cultural Monsenhor Chaves, p. 5-18. (2011). Os literatos e a República: Clodoaldo Freitas, Higino Cunha e as tiranias do tempo. 3. ed. Teresina: EDUFPI.

(2015). Poesia e trabalho na ressaca da Belle Époque. In: História, literatura, sociabilidades. 2. ed. Teresina: EDUFPI/APL. 
SEVCENKO, Nicolau (2003). Literatura como missão: tensões sociais e criação cultural na Primeira República. São Paulo: Companhia das Letras.

WILLIAMS, Raymond (1992). Cultura. Rio de Janeiro: Paz e Terra.

Artigo recebido em 30 de agosto de 2016.

Aprovado em 25 de março de 2017.

DOI: $10.12957 /$ intellectus.2017.31658 